\title{
Erratum to: Giant cell tumour of manubrium sterni - a rare case
}

\author{
Gautam Sengupta • Anup Charles • Mohammad Shahbaaz Khan • \\ Mohammad Zahid Hossain
}

Published online: 10 March 2013

(C) Indian Association of Cardiovascular-Thoracic Surgeons 2013

Erratum to: Indian J Thorac Cardiovasc Surg (JulySeptember 2012) 28(3):188-190

DOI 10.1007/s12055-012-0131-y

The original version of this article contains mistake on the article title. "Gaint" should be "Giant". The corrected version can be seen above.

The online version of the original article can be found at http:// dx.doi.org/10.1007/s12055-012-0131-y.

G. Sengupta $\cdot$ A. Charles $(\bowtie) \cdot$ M. S. Khan $\cdot$ M. Z. Hossain

Department of Cardiothoracic and vascular surgery,

S.S.K.M. Hospital, Institute of Postgraduate Medical

Education and Research,

242 AJC Bose Road,

Kolkata 70020, India

e-mail: anupcharles@yahoo.com

G. Sengupta

e-mail: sengupta.gautam@gmail.com

M. S. Khan

e-mail: mohdshahbaazkhan@yahoo.com 